\title{
Komplekse liv: Patientinddragelse som vej til et bedre hverdagsliv for multisyge?
}

Lisbeth Ørtenblad, Alexandra Ryborg Jønsson \& Lucette Meillier

Folkesundhed og Kvalitetsudvikling, Region Midtjylland ViBIS

Folkesundhed og Kvalitetsudvikling, Region Midtjylland lisbeth.oertenblad@stab.rm.dk,aj@vibis.dk,lucette.meillier@stab.rm.dk

Ørtenblad, L., Jønsson, A. R. \& Meillier, L. (2015). Komplekse liv: Patientinddragelse som vej til et bedre hverdagsliv for multisyge?, Tidsskrift for Forskning i Sygdom og Samfund, nr. 22, 83-101.

Med udgangspunkt $i$ tre cases fra et feltarbejde blandt mennesker med multisygdom beskriver forfatterne en række temaer i informanternes hverdagsliv - social identitet, nære relationer og sygdomsforståelse - som vigtige for forstålse af multisyges oplevelse af kompleksitet $i$ sygdomsforløb. I artiklen præsenteres data, der peger i retning af, at hverdagsliv har væsentlig indflydelse på patienternes prioriteringer af behandling og egenomsorg. Der argumenteres for, at særligt multisyge patienter har brug for at blive inddraget $i$ beslutninger om behandling og pleje, fordi kompleksiteten af deres sygdomsforløb påvirker hverdagen $i$ betydelig grad. 


\section{Complex lives: Patient involvement as key to improving everyday life for people with multiple diseases}

This article is based on ethnographic fieldwork among people with multiple diseases. The authors present three cases describing different aspects of how the burden of multiple diseases and the burden of their treatments influence patients' everyday life and social identity. The data shows that patient's perceptions of diseases and their management of them in everyday life has an extensive influence on the relation between health staff and patients. Following this, the authors argue that patient involvement with a focus on the individual patient's everyday life, perceptions of diseases and social situation can be a key to an efficient collaboration a well-functioning partnership between patients and health staff. It is shown that especially for people with multiple diseases it is important to be involved in decisions about treatment and care, because the complexity of their disease has a profound influence on everyday life and prioritization of treatment and self-care.

\section{Indledning}

Sygdom er ikke blot en fysisk tilstand, men også et socialt fænomen. Når vi bliver syge, påvirkes hverdagen og vores sociale identitet. Afhængig af sygdommens karakter kan vi risikere at tabe tilhørsforholdet til sociale fællesskaber, og den måde vi håndterer og forstår sygdommen påvirkes. Hvis man er multisyg, det vil sige har flere samtidige, langvarige eller kroniske sygdomme (van der Akker 1996, WHO 2013), vil den negative indflydelse på hverdagslivet øges, eksempelvis ved akkumulerende smerter, træthed og nedsat livskvalitet. I denne artikel belyses, hvorledes de mange forskellige facetter af hverdagslivet som multisyg, herunder forståelse af sygdommene, sygdomskompleksitet og individuelle ressourcer til håndtering af sygdom, gensidigt påvirker hinanden og præger samarbejdet med sundhedsvæsenet. Udgangspunktet er tre menneskers fortællinger om deres liv med multisygdom. Disse sygdomsfortællinger er eksempler på, hvordan mennesker med multisygdom på hver deres måde håndterer sygdomsbelastning, samt hvordan de prioriterer behandlinger og navigerer i det danske sundhedssystem, som er monodiagnostisk organiseret. I fortællingerne udfoldes en række temaer social identitet, nære relationer og sygdomsforståelse - som har betydning for den kumulative kompleksitet, de fleste multisyge patienter oplever. Hverdagslivet, som det udspiller sig i relation til blandt andet disse temaer, viser sig afgørende for, hvorledes samarbejde med sundhedsvæsenet foregår. Med artiklen ønsker vi 
at vise, hvordan patienterne agerer strategisk i kløften mellem den kliniske virkelighed og deres hverdagsliv.

\section{Multisygdom}

At leve med multisygdom bliver mere og mere almindeligt internationalt såvel som i Danmark (Wolff, Starfield \& Anderson 2002; Barnett et al. 2012; Sundhedsstyrelsen 2014:36). Det skyldes blandt andet forbedrede behandlingsmetoder, bedre overlevelsesmuligheder ved livstruende sygdomme samt den demografiske udvikling med et stigende antal ældre, som har højere forekomst af kroniske sygdomme.

Forekomsten af multisygdom er stigende med alderen, og over halvdelen af den danske befolkning over 65 år er multisyge (Sundhedsstyrelsen 2014:36). Patienter med multisygdom har højere mortalitet (Tinetti et al. 2011). Forskning viser endvidere, at multisygdom påvirker livskvaliteten, og at smerter og træthed stiger med antallet af kroniske sygdomme hos den enkelte patient (Lawson et al. 2012, Fortin et al. 2007). Overskud til at deltage i eksempelvis rehabilitering påvirkes i negativ retning ved multisygdom (Meillier et al. 2012), og det øger samtidig risikoen for at udvikle nye sygdomme (van der Akker et al. 1998).

Det er karakteristisk, at multisygdom både er præget af og bidrager til social ulighed. Multisygdom forekommer oftere blandt mennesker med en ufaglært, faglært eller kort boglig uddannelse end blandt højtuddannede. Desuden er der færre ufaglærte og kortuddannede multisyge i beskæftigelse end langvarigt uddannede multisyge. Uligheden forstærkes jo flere samtidige sygdomme man har, eksempelvis påvirkes funktionsevnen mere i lavindkomstgrupper end i højindkomstgrupper (Sundhedsstyrelsen 2014, Lawson et al. 2012).

Tilstedeværelsen af flere samtidige kroniske sygdomme medfører mange og ofte komplekse behandlingstilbud. Det stiller det specialiserede sundhedsvæsen over for en udfordring (Reventlow et al. 2013). For den enkelte patient kan de mange behandlinger opleves som en anseelig byrde, hvilket kan påvirke den multisyges håndtering af sygdommene i negativ retning - for eksempel i form af at afbryde behandlinger, at undlade at deltage i regelmæssig kontrolbesøg eller at opleve problemer på grund af interagerende behandlinger (Smith, O'Kelly \& O’Dowd 2010; Schippee et al. 2012). Tilsvarende oplever de sundhedsprofessionelle patienter med multisygdom som tids- og ressourcekrævende (Barnett et al. 2012; Moth, Vestergaard \& Vedsted 2012), blandt andet de alment praktiserende 
læger oplever at mangle kompetencer til at håndtere de interagerende forhold for patienten (Smith, O'Kelly \& O'Dowd 2010). Det er også påvist, at multisygdom øger antallet af afvigelser fra kliniske retningslinjer (Roland \& Paddison 2013), hvilket kan være udtryk for den kompleksitet, som de mange og måske interagerende behandlinger udgør.

\section{Felt og metode}

Artiklen tager afsæt i et antropologisk studie af multisygdom og ulighed i det behandlende sundhedsvæsen ${ }^{1}$. Studiet omfattede et litteraturstudie ${ }^{2}$, fokusgruppeinterview ${ }^{4}$ med mennesker med multisygdom samt interview og deltagerobservation gennem cirka et år med 10 patienter. Disse 10 nøgleinformanter blev udvalgt dels blandt fokusgruppeinterviewdeltagerne, og dels kontaktet via patientforeninger eller gennem opslag hos alment praktiserende læger. Informanterne blev fulgt med henblik på at belyse betydning af hverdagsliv med multisygdom for samarbejde med sundhedsvæsenet med et særligt fokus på den konkrete interaktion mellem sygdomsbyrde og behandlingsbyrde. Nøgleinformanterne blev interviewet i deres hjem eller på en passende lokation ud fra en semistruktureret interviewguide samt fulgt ved besøg hos egen læge, hos speciallæger, $i$ andre kontakter med sundhedsvæsenet, til samtale på jobcenter samt til sociale aktiviteter, som havde betydning for deres hverdagsliv. Informanterne fordelte sig på fire kvinder og seks mænd i alderen 36 - 71 år; de fleste var mellem 44-55 år, og en enkelt var 71 år. Informanterne havde tre til syv sygdomme, de fleste af dem firefem sygdomme hver. Næsten alle havde gigt, og desuden var diabetes, hjerte-kar sygdomme og ryglidelser almindelige. Enkelte havde også KOL, inflammatorisk tarmlidelse, astma/allergi, migræne eller generaliserede smerter. Derudover havde de fleste oplevet i perioder at have depression eller angst i tilknytning til deres somatiske sygdomme. Fire af personerne var blevet syge i en ung alder - i løbet af 20'erne - mens de øvrige typisk begyndte at blive syge, da de var mellem 40-50 år.

Hos en enkelt af informanterne indgik en pårørende i væsentligt omfang i feltarbejdet. Det skyldes, at de to havde et meget tæt samarbejde om håndtering af informantens kroniske sygdomme, og fordi hverdagslivet var studiets krumtap, deltog den pårørende som en naturlig del af undersøgelsens gennemførelse. Artiklen beskæftiger sig ikke eksplicit med pårørendeproblematikker, men inddrager pårørendeaspekter i det omfang det er nødvendigt for forståelse af informanternes hverdagsliv med sygdommene. 


\section{Komplekse liv - tre cases}

Artiklen fokuserer på tre af de i alt 10 cases, der indgik i det samlede antropologiske feltarbejde. Forfatterne har sammenfattet de tre fortællinger om sygdomsforløb på baggrund af interview, observationer under besøg med informanterne i sundhedsvæsenet og andre aktiviteter i hverdagslivet. De tre cases er udvalgt her, fordi de viser den spændvidde i måder at håndtere sygdomme og behandlinger, $\mathrm{i}$ tilgængelige ressourcer, og i strategier til samarbejde med sundhedsvæsenet, som generelt er fundet i det empiriske materiale.

Nedenfor introduceres en model til analyse af kumulativ kompleksitet blandt multisyge (Shippee et al. 2012), der fungerer som studiets analytiske ramme, og der er således valgt en teoridreven tilgang til analysen. Med dette afsæt peger analysen af det empiriske materiale på tre temaer: social identitet, nære relationer og sygdomsforståelse, som centrale for forståelse af multisyges oplevelse af kompleksitet i sygdomsforløb.

\section{Multisygdom og kumulativ kompleksitet}

Shippee et al. (2012) har beskrevet relationen mellem en patients arbejdsbyrde med at passe sine sygdomme og de kapaciteter vedkommende har fysisk, økonomisk, intellektuelt og socialt. Oplevelsen af arbejdsbyrde øges, når der er mange handlinger forbundet med sygdomshåndtering i hverdagen, hvis disse er svære at udføre, eller hvis de ikke passer sammen. Personens fysiske og mentale funktionsniveau, smerter, symptomer, træthed, økonomiske formåen, evne til at tilegne sig viden, og personens støtte fra eget netværk og fra professionelle har betydning for kapacitet til at håndtere behandlingsbyrden og for patientens evne og muligheder for at navigere i sundhedsvæsenet (ibid.). Disse forhold - sygdomsbyrde, arbejdsbyrde og kapacitet - kompliceres yderligere for hver forværring eller ny sygdom, der kommer til. Balancen mellem arbejdsbyrde og kapacitet kan tippe, så der opstår risiko for forstyrrelser, afbrydelser eller sammenbrud i behandlinger og i relationer mellem den syge og sundhedsprofessionelle. Hvornår og hvordan, det kommer til udtryk, er afhængig af den enkelte persons samlede ressourcer (kapacitet) i forhold til vedkommendes sygdomsudvikling (sygdomsbyrde). Med afsæt i Shippee et al.'s analyse af kumulativ kompleksitet ved multisygdom ønsker vi med de følgende cases at vise, hvorledes udvikling og håndtering af kroniske sygdomme er relateret til og påvirket af den multisyges hverdag. 


\section{Social identitet}

Multisygdom indebærer ofte ændringer i identitet og selvopfattelse. Sygdommene medfører omfattende fysiske og mentale begrænsninger med konsekvenser for den syge persons arbejdsmuligheder og for sociale og familiemæssige relationer. Det påvirker forståelse af, hvem man er som person, og hvorledes man kan agere i sin omverden. Tilstedeværelsen af flere kroniske sygdomme potenserer denne udvikling.

\section{Case 1: "Jeg er jo vant til at trække lægerne rundt i manegen"}

Søren er 58 år. Han er skilt, og lever alene med den yngste af sine to børn boende hos sig cirka hver anden uge. Sørens sygdomsforløb startede, da han som ganske ung flere gange fik blodpropper i begge ben. Flere sygdomme er kommet til; udover tilbagevendende blodpropper i ben og lunger har Søren i dag forhøjet blodtryk og er hjertesyg, han har KOL, diabetes, slidgigt, og lider også af søvnapnø. Søren er overvægtig, har dårlige knæ og har derfor besvær med at bevæge sig. Han har et omfattende medicinbrug og tager 10-12 forskellige præparater hver dag. Søren har smerter næsten konstant, han sover dårligt og føler sig ofte ukoncentreret og træt. Søren fortæller, at det er blevet sværere at klare sig i hverdagen, efter at han i forbindelse med sin nylige skilsmisse også har fået angstanfald og en depression.

Som ung dyrkede Søren gymnastik på højt niveau, men både det og adskillige forsøg på uddannelsesforløb har han måttet opgive efterhånden, som sygdommene tog til. Han har som yngre haft mange forskellige ufaglærte jobs. Siden er Søren blevet selvstændig, og har gennem årene opbygget adskillige virksomheder, som han i dag hovedsageligt administrerer som bestyrelsesmedlem og igennem medarbejdere. Søren beskriver sig selv som 'fuldtidssyg', fordi hans hverdag er optaget af at tage hensyn til og passe de mange sygdomme. Men på trods af det ser Søren sig selv som ressourcestærk i den måde, han har tacklet livets udfordringer på, og han er fast besluttet på at arbejde på at få så godt et liv som muligt på trods af de fysiske og mentale begrænsninger, som er konsekvenser af de mange sygdomme.

Om sit samarbejde med sundhedsvæsenet siger Søren: "Jeg skal selv gøre opmærksom på alt, skal selv orientere dem [sundhedspersonale] og skal selv koordinere. Ingenting sker, hvis man ikke selv gør opmærksom på det. Men jeg er jo vant til det, jeg er vant til at trække lægerne rundt $i$ manegen". Søren køber sig ofte til ydelser på privathospitaler både i Danmark og i udlandet, fordi han synes, at han får utilstrækkelig 
hjælp i sundhedsvæsenet. Han fortæller om et ophold på en behandlingsklinik i udlandet:

"Der tabte jeg mig, rigtig meget - næsten $28 \mathrm{~kg}$. (...). Det meste af det, jeg har tabt mig, det er jo bare vand i kroppen, som kommer af bivirkninger af al den medicin, jeg tager. Jeg synes simpelthen, det er underligt, at ingen gør mig opmærksom på det, og at jeg selv skal finde ud af alt det. Jeg synes, det er for dårligt, at ingen reagerer, og at det skal komme så vidt.(.....). Min fordel er jo, at jeg har orden i økonomien, så jeg ind imellem kan købe behandling og hjælp, når nu sundhedsvæsenet ikke leverer. Men det er anstrengende oveni at være syg".

Søren synes ikke, sundhedspersonalet forstår de problemer, han har, eksempelvis hans behov for hjælp til at kunne overskue de mange behandlinger, interaktion mellem sygdommene og bivirkninger af medicin. Når han reagerer på det i sin vedholdende efterspørgsel på koordinering af behandlinger, undersøgelser og andre indsatser, har han samtidig en oplevelse af afhængighed af hjælp fra sundhedsprofessionelle. Han siger:

"Jeg vil jo helst klare mig selv, og jeg arbejder hele tiden på at kunne klare mig selv så meget som muligt og få så lidt hjælp som muligt. Det irriterer mig med al den kontakt med sundhedsvæsenet, og det betyder for eksempel, at jeg tit ikke har mulighed for at tage mig af min datter, eller at jeg simpelthen ikke kan lave andet end at være syg".

Søren har en oplevelse af, at han ikke bliver mødt med respekt. Han siger for eksempel:

"Jeg bliver negligeret. Og det er jeg altså ikke vant til. Det må jeg sgu indrømme. Så får jeg at vide, 'der er lige kommet noget andet ind, og der er lige kommet noget andet ind' - men jeg har altså ligget her i to dage, og dengang var jeg også lige kommet ind! Så jeg vil godt tale med en læge NU".

Oplevelsen af at Søren negligeres deles ikke nødvendigvis af de sundhedsprofessionelle. For eksempel fremgår det under en konsultation på en hospitalsafdeling, at Søren mener, en nylig indlæggelse blev nødvendig, fordi han blev udsat for fejlmedicinering på grund af manglende koordinering mellem to afdelinger, han blev overflyttet imellem. Sygeplejersken mener derimod, at indlæggelsen skete, fordi Søren reagerede på ændringer i medicin, som han foretog uden at tale med sundhedspersonalet om det. 


\section{Multisygdom og identitetsarbejde}

Som ovenstående illustrerer, manifesterer der sig et dilemma mellem at blive set som den myndige og handlekraftige mand, Søren var, og en accept af afhængighed af andre som patient . I sin bog fra 1996 om social identitet beskæftiger Richard Jenkins sig med samspillet mellem den personlige og den sociale identitet. Jenkins beskriver her, hvorledes mennesker definerer sig via tilknytning til sociale grupper og fællesskaber, samt hvorledes en persons selvopfattelse spejler sig i vedkommendes sociale omgivelser og i andre menneskers opfattelse af personen (Jenkins 2006). At vise hvem man er, er et grundlag for etablering af meningsfulde relationer, hvilket finder sted i hverdagslivets handlinger og i relationer mellem selvet og omgivelserne. Identitet er ifølge Jenkins ikke en fast størrelse, men et produkt af dynamisk og processuel forhandling. Eksemplificeret i Sørens case fandt vi i studiet, at vores informanter bevægede sig i et spændingsfelt mellem på den ene side at fastholde den tidligere, raske identitet og samspillet med de sociale relationer, og på den anden side at forsone sig med det at være syg, dvs. den måde han fremstår bl.a. i sit samarbejde med sundhedspersonale. Søren arbejder med at fastholde sig selv i rollen som succesrig entrepenør, samtidig med at sygdommens fysiske byrde tvinger ham til at være afhængig af andres hjælp. Aujoulat et al. (2008) har beskrevet dette identitetsarbejde som et spændingsfelt mellem at fastholde sin selvforståelse som rask person, der har kontrol over sin kendte tilværelse og en pågående nødvendighed af at justere på dette selvbillede. Det illustrerer en bevægelse mellem 'at fastholde den man var' (beskrevet som 'holding on'), hvilket er knyttet til bestræbelser på at genvinde en følelse af kontrol over handlinger og aktiviteter i tilværelsen, og 'en forsonende proces' (beskrevet som 'letting go') der er knyttet til en erkendelse, og måske accept af, at de ændrede fysiske betingelser har indflydelse på udfoldelser i hverdagen og dermed også på ens sociale liv og personlige identitet. Måske derfor oplever Søren at befinde sig $i$ et system, hvor han ikke føler sig imødekommet og forstået, og hvor han i vid udstrækning er nødt til at acceptere den behandling, der tilbydes, selvom det ikke svarer til hans opfattelse af acceptabel og hensigtsmæssig hjælp. Det kommer til udtryk i samarbejdet med de sundhedsprofessionelle, som i kraft af Sørens ønske om at opnå respekt og anerkendelse fra de sundhedsprofessionelle kommer til at fremstå som en kamp om at få den fortolkning af hans sygdomme og behandlinger, som han forventer. Konsekvensen i Sørens case er, at han indimellem afbryder, ændrer eller iværksætter behandlinger uden nødvendigvis at drøfte det med sundhedspersonale. 


\section{Sygdomme i hverdagen og de nære relationer}

At være multisyg medfører både en øget sygdomsbyrde og behandlingsbyrde i hverdagen. Håndtering af disse er afhængig af, hvorledes elementerne i den samlede kapacitet er stykket sammen i det, som tilsammen sætter rammerne for personens hverdagsliv. Med den følgende case ønsker vi at vise, at dette ikke blot gælder personens fysiske og mentale funktionsniveau, økonomiske formåen, evne til at tilegne sig viden mv., men i høj grad også kapacitet i vedkommendes sociale netværk.

\section{Case 2: "Før løb jeg jo heller ikke maraton, vel"}

Hanne er 65 år. Hun var hjemmegående, mens familiens børn var små, og har derefter haft forskellige jobs med rengøring, i butik og på plejehjem. Allerede dengang oplevede hun ofte ikke at kunne magte sit arbejde på grund af sygdom, og hun fortæller, at det derfor var en stor lettelse, da hun for nogle år siden fik tilkendt førtidspension. Hanne har været gift med Peter, siden de var ganske unge. Både Hanne og Peter, deres børn og børnebørn tilhører en menighed, som har stor betydning for familiens livsform og for deres omgangskreds. Det er altafgørende for Hannes håndtering af sine sygdomme i hverdagen, og troen og håbet er det, der gør, at hun ikke giver op, siger hun.

Hanne var i midten af 30'erne, da hun fik konstateret leddegigt, og siden er andre sygdomme og symptomer kommet til: Sjøgrens syndrom, KOL, dårlig ryg samt migræne, som dog er aftagende. Sidste år fik Hanne også en voldsom depression, hvilket hun omtaler som meget værre end sine somatiske sygdomme. Sygdommene fylder meget i Hannes liv og i familiens dagligdag. Hanne passer med stor omhu og med hjælp fra sin mand alle sine aftaler og behandlinger i sundhedsvæsenet. Hun går til regelmæssig kontrol af gigt og KOL, modtager regelmæssigt intravenøst gigtmedicin samt regelmæssige besøg hos egen læge for blodprøvetagning før kontrolbesøgene i det specialiserede sundhedsvæsen. De forskellige sygdomme medfører en lang række andre symptomer, så også hyppige besøg hos tandlæge, øjenlæge og andre speciallæger skal passes. Hertil kommer bestilling og afhentning af medicin. Også akutte episoder fylder meget. Hanne får for eksempel ofte betændelsestilstande forårsaget af en ny gigtmedicin, hun har problemer med slimhinder på grund af Sjøgrens syndrom, og med jævne mellemrum problemer med maven. Gennem det år forfatterne har fulgt Hanne, har hun kontakt med sundhedsvæsenet en til to gange om ugen. 
Det er vigtigt for Hanne, at sygdommene fylder så lidt som muligt i dagligdagen. Hun siger for eksempel:

"Jeg spekulerer ikke rigtig over det med sygdom. Men når du [forfatteren] nu spørger, så er jeg jo nødt til at tænke over, hvordan det påvirker mig. Men jeg tænker ikke over det sådan til daglig - det er en del af hverdagen. Selvfølgelig bliver jeg bremset, men jeg har bestemt mig for ikke at føle mig bremset. For lang tid siden besluttede jeg, at sygdom ikke skulle få lov at bestemme. Jeg er bare begrænset i min udfoldelse. Det er sådan det er. Jeg er bare mig, og så er der ting, jeg ikke kan......... Jeg kan jo ikke løbe maraton, vel, men det gjorde jeg jo heller ikke før".

Hannes mand Peter er afgørende for pasning af Hannes sygdomme, så han kommer naturligt til at indgå i feltarbejdet, selvom det ikke var planlagt fra starten. Det er Peter, som sørger for transport, når Hanne skal til møder i sundhedsvæsenet, han henter ofte medicin og går med til konsultationer, han har lært sig at lave mad, han står nu for det meste af rengøring og indkøb. Peter hjælper Hanne med personlig pleje, eksempelvis har han lært at hjælpe Hanne med at lægge make-up, og han støtter og hjælper, når de er på ture, besøger familie og er til møder i deres menighed. Peter har sukkersyge, men det fylder ikke i familiens hverdag. Han fortæller blot, at det er velreguleret, og at han i sin livsstil tager hensyn til sygdommen.

Under et besøg hos familien fortæller Peter, at det indenfor de sidste to år er gået stærkt tilbage med Hanne. Det kan Hanne ikke lige genkende, siger hun, men giver alligevel udtryk for, at hendes position i familien er ændret, fordi hun magter mindre, hvilket går hende på. Hun synes for eksempel, at hun ikke længere kan bestemme i køkkenet, hvordan maden skal tilberedes, og hvad de skal have, når det er de andre, der skal lave arbejdet, som hun siger. Hun er ofte træt i hverdagen og må prioritere, eksempelvis er hun ikke længere så aktiv i sin menighed, som hun ønsker at være, og som hun plejer. Men akkumulationen af sygdomme får på ingen måde konsekvenser for hendes brug af sundhedsvæsenet. Prioriteringerne finder i stedet sted i familien, hvor især Peter, men også de øvrige familiemedlemmer, i tiltagende grad kompenserer for de begrænsninger, som sygdommen medfører for Hanne i hverdagen. Peter fortæller:

"Det generer på den måde, at man hele tiden skal planlægge og hele tiden tænke fremad. Jeg kan jo ikke bare gå ud i haven nu, hvis det er godt vejr, når der er ting, Hanne skal hjælpes med først. Vi skal planlægge dagen efter, om Hanne skal noget med læge og den slags. Der er også flere ting, vi ikke længere kan gøre. Mine 
aktiviteter er blevet reduceret betragteligt de senere år, sådan er det blevet. Men når man kan klare hinanden i gode tider, så må vi også kunne klare det, når det er knap så godt".

\section{Multisygdoms kumulative kompleksitet i hverdagen}

Shippee et al.'s model af sygdomsforløbs kumulative kompleksitet illustrerer, hvorledes tilvækst af nye sygdomme og symptomer og den samlede kapacitet til håndtering af den medfølgende behandlingsbyrde gensidigt påvirker hinanden (Shippee et al. 2012). Analysen af vores empiriske materiale viser, at den konkrete manifestation af relation mellem kapacitet og behandlingsbyrde og sygdom er relateret til den syge persons hverdagsliv. Behandlingsbyrden ved at passe sine sygdomme og de fysiske, økonomiske og sociale kapaciteter er elementer som ligger til grund for arbejdsglidning og de ændrede familieroller, der finder sted i Hannes familie. I forlængelse af Shippee et al.'s analyse af kumulativ kompleksitet ved multisygdom vil vi tilføje, hvad vi finder er et meget væsentligt aspekt, nemlig at patienter og pårørende kan have vidt forskellige opfattelser af arbejdsbyrden ved sygdomme og af familiens kapacitet. Hannes tilgang til sine sygdomme er, at hun må acceptere sine begrænsninger og leve videre. Hendes reaktioner på den nedadgående spiral med sygdomme, der eskalerer, er primært af social og identitetsmæssig karakter, mens hendes mand Peter kompenserer for den tiltagende belastning, som behandlingsbyrden udgør, ved i hverdagen at påtage sig en stigende mængde af praktiske anliggender ved Hannes sygdom. Det betyder blandt andet, at han må give afkald på social interaktion uden for familien, men det betyder også, at Hanne kan passe sine aftaler og behandlinger i sundhedsvæsenet. For de af vores informanter der ikke har et lignende netværk at trække på, betyder det omvendt, at der må fraprioriteres i sociale interaktioner og i kontakter med sundhedsvæsenet i takt med multisygdommens kumulative kompleksitet. Det skal vi i det følgende afsnit se et eksempel på. 


\section{Sygdomsforståelse og skiftende prioriteringer i behandling}

I vores materiale varierer den enkelte persons forståelse af sygdomme fra uafhængige og serielt opstået, til at sygdommene relaterer sig til hinanden, således at én sygdom er årsag til, at den næste udviklede sig eller fik de konsekvenser, den gjorde. Nogle forstår således deres sygdomme som helt uafhængige og kan håndtere dem serielt uden større problemer i monodiagnostisk kontakt med sundhedsvæsenet. Eksempelvis Hanne, som med støtte fra sin mand håndterer og passer sine sygdomme enkeltvis, og følger de behandlingsregimer og aftaler med sundhedsvæsenet, som hun indgår i. Andre forstår sygdommene som interagerende, og kan opleve det kaotisk og uoverskueligt, når ændring af behandling ved en af sygdommene får konsekvenser for behandlingen af en anden sygdom. Den efterfølgende case er en illustration af, hvorledes forståelsen af sygdommene har betydning for oplevelsen af behandlingsbyrden og for, hvordan og hvornår balancen mellem sygdomsbyrde og arbejdsbyrde ved behandling tipper.

\section{Case 3: "Jeg ved ikke om det er på grund af den der sukkersyge, jeg synes også, jeg er mere træt"}

Oleg er 44 år og flyttede til Danmark fra Polen for 20 år siden, da han mødte en kæreste. De er siden gået fra hinanden. Nu har Oleg en polsk kæreste, som for tiden opholder sig hos ham i Danmark. Oleg taler dansk, men mangler ind imellem ord. Kæresten forstår ikke dansk eller engelsk. Oleg er ufaglært, og han har haft forskellige typer af jobs. I dag er han tilkendt førtidspension på grund af leversygdom og alkoholisme. Før i tiden drak han cirka 40 øl dagligt, og han plejede at færdes meget i gademiljøet. Han fortæller, at han nu kun drikker fem øl om dagen, og at det er sjældent, han drikker sig fuld. Den udvikling er han meget stolt af.

Oleg sygdomsforløb startede i 1995 ved et fald, som medførte en alvorlig hovedskade. Siden er andre sygdomme kommet til, og i dag har Oleg skrumpelever, åreknuder og blødning på spiserøret, problemer med nerver i den ene arm, smerter i benene, diabetes, træthed, svamp og andre fysiske skavanker. Ind imellem oplever han også angstanfald. Oleg har været indlagt 75 gange siden 1995. Økonomisk set er det et problem for ham med medicinudgifter, og han oplever også bivirkninger ved medicinen, blandt andet har han taget $20 \mathrm{~kg}$. på i løbet af de sidste to år. Smerter i benene gør det vanskeligt for ham at komme rundt. Dagene går med 
at se tv eller opholde sig på et værested for pensionister, hvor han arbejder med at svejse og lave træarbejde. Oleg fortæller, at han ville ønske, at han kunne tabe sig, få stærke ben og bevæge sig mere. Derudover fortæller Oleg ikke ret meget om sig selv uopfordret.

I en af forfatternes samvær med Oleg på besøg på hospital og ved egen læge fremgår det tydeligt, at Oleg oplever flere problemer i sit møde med sundhedsvæsenet. Eksempelvis i forbindelse med et ambulant kontrolbesøg på sygehuset, hvor Oleg virker forvirret over de mange aktiviteter og spørgsmål. Han lader til at have svært ved at finde ordene og til at kende undersøgelser fra hinanden. Han har vanskeligt ved at skelne mellem sygdomme og bivirkninger samt ved at forstå, hvorfor en given behandling foreslås. Han undersøges blandt andet for en knude på halsen, og bliver i den forbindelse sat $\mathrm{i}$ et pakkeforløb for udredning af cancer. Da han taler med en af forfatterne senere, kommer det frem, at han ikke rigtig forstod, hvad der skulle ske. Oleg oplever også forståelsesmæssige barrierer som at blive henvist til fysioterapi, som han ikke ved, hvad er.

Oleg synes, der er kommet mange problemer til det sidste år. Deriblandt diabetes, vitaminmangel, et brækket ben og hævelser i benene, så han har nok at passe, siger han. Han har for noget tid siden droppet det vitamintilskud, han af en læge blev anbefalet at tage dagligt. Hans forklaring er, at han får ondt i maven og forstoppelse af tabletterne, især nu hvor han ikke kan bevæge sig så meget. Under konsultationen fortæller lægen ham, at der er sammenhæng mellem B12-vitaminmangel, jernmangel og nogle af hans symptomer blandt andet den umådelige træthed. Den sammenhæng kender Oleg ikke til. Lægen fortæller også Oleg, at skrumpelever er årsag til vitaminmangeltilstandene, da leverens funktion er i tiltagende forringelse, og at det derfor vil være bedst helt at holde op med at drikke. Oleg vidste ikke, at der er sammenhæng mellem skrumpeleveren og mangel på B12 vitamin og jern. Når han fortæller om sine sygdomme og tilstande - både til en af forfatterne og hos lægen - beskriver han dem som uafhængige af hinanden. Vitaminmanglen er imidlertid så udpræget, at han bliver rådet til indsprøjtninger, men Oleg er bange for nåle. Han er godt tilfreds med at have fået sit alkoholforbrug ned på fem øl om dagen, og han giver derfor udtryk for både forvirring og skuffelse, da sundhedspersonalet fortæller ham, at han har et valg mellem vitaminindsprøjtninger eller helt at ophøre med at drikke alkohol for at stabilisere sin leverfunktion. 


\section{Flere sygdomme - flere valg der skal træffes}

Individuel forståelse af sammenhæng og samspil mellem sygdommene påvirker den syge persons vurderinger, oplevelser og valg af behandlinger og af egenomsorgs strategier (Sharry et al. 2013).

Informanternes forståelse af deres flere samtidige sygdomme påvirker således de foretrukne egenomsorgsstrategier. Der kan opstå vanskeligheder med at forstå personalets intentioner, hvis de adresserer en sygdom, som aktuelt ikke har højeste prioritet, eller hvis en nødvendig egenomsorgshandling overses. Forståelserne af sygdommenes sammenhæng og af egne ressourcer og præferencer er vigtige at afklare for at undgå misforståelser og råd og anvisninger, der ikke følges. Oleg accepterer under konsultationen at få indsprøjtninger, men under det følgende feltarbejde blev det klart for forfatterne, at Oleg valgte at prioritere anderledes. Han udeblev fra sine aftaler i sundhedsvæsenet, fordi de fem øl om dagen var mere afgørende for hans livskvalitet end den oplevede sygdomsbyrde.

Uoverensstemmelserne mellem sundhedspersonalets og Olegs forståelse af sygdommenes sammenhæng medvirker til at balancen mellem sygdomsbyrde og behandlingsbyrde tipper, i den forstand at sundhedspersonalets forslag om behandlinger opleves som behandlingsbyrde, fordi de ikke harmonerer med hans sygdomsforståelser og fysiske, psykiske og sociale kapaciteter. For Oleg betyder det en vanskelig beslutning, om han har de sociale og psykiske ressourcer til helt at afholde sig fra at drikke alkohol for eksempel, eller om alternativet med indsprøjtningerne er acceptable.

\section{Brugerinddragelse i sundhedsvæsenet}

De tre cases, vi har præsenteret i artiklen, tegner et billede af en gruppe mennesker, for hvem hverdagen er præget af udfordringer med sygdomme såvel som med behandling. Hverdagslivet, som det udformer sig for den enkelte multisyge person, viser sig at have væsentlig betydning for, hvorledes samarbejde med sundhedsvæsenet foregår. Den individuelle forståelse af, hvorledes sygdomme hænger sammen og håndtering af dette i hverdagen har eksempelvis afgørende indflydelse på, hvorledes til og fravalg af behandlinger og samarbejde med sundhedsprofessionelle konkret udspiller sig. På trods af behandlinger der droppes ud af, handlinger der strider imod sundhedsprofessionelles anbefaling, belastning af familiære og sociale relationer med videre, agerer alle de multisyge patienter, vi 
har fulgt, strategisk, meningsfuldt og ud fra en egen overbevisning om, hvad der er den rette og hensigtsmæssige behandling, og patienterne søger derigennem at agere strategisk i kløften mellem den kliniske virkelighed og deres hverdagsliv. Vores materiale viser, at der er risiko for, at der ikke skabes en relation mellem den kliniske virkelighed og patientens hverdagsliv, når patienten ikke er inddraget $\mathrm{i}$ behandlingsbeslutningerne, og når prioriteringerne i deres hverdagsliv ikke er en del af beslutningsprocesserne. Det ser vi eksempelvis, når Søren selv må sammenkoble sin vægtforøgelse og den ordinerede medicin. Sørens hverdagsliv påvirkes, og han vælger selv at ændre på sin behandling eller betale for en anden behandling i udlandet. Vi ser også, hvordan Oleg ikke formår at skabe sammenhæng mellem et hverdagsliv med moderat alkoholforbrug og sin skræk for nåle på den ene side, og den kliniske behandling af hans sygdomme på den anden. Det bliver et enten eller valg. Og vi ser, hvordan Hannes tiltagende sygdomme og arbejde med at imødekomme den tilsvarende behandlingsbyrde sker på bekostning af de samlede kapaciteter i hendes nære miljø.

En øget opmærksomhed på patientinvolvering kan måske bidrage til løsning af nogle af de problemer, der præsenteres i ovenstående cases. For multisyge patienter gælder det særlige, at de også skal fungere som tovholder på flere forskellige forløb, og de og eventuelt deres nære relationer er dem der har størst indsigt i det samlede behandlingsbillede og som kender forløbet i sin helhed. Det er generelt afgørende for behandlingskvaliteten, at lægen lytter til patientens behov og identificerer mål, så der i fællesskab kan træffes en beslutning om, hvilke behandlinger der er mest egnede (Roland \& Paddison 2013). For multisyge kompliceres dette, fordi både sygdomsbyrde og behandlingsbyrde er akkumulerende.

For alle de multisyge patienter vi har fulgt gælder det, at behandlingerne udfordres af hverdagslivet og den konstante forhandling af social identitet, der udfolder sig på et kontinuum mellem syg og rask. Med inspiration i Jenkins' arbejde med identitet som en social størrelse, der mere eller mindre konstant forhandles i en dynamisk proces, har vi vist, hvorledes identitetsarbejde for mennesker med multisygdom bliver et væsentlig parameter, der har betydning for de relationer som udspiller sig i hverdagslivet - også for relationer til og samarbejde med sundhedsprofessionelle. Håndtering og forståelser af sygdommene, de sociale omgivelsers reaktioner og konsekvenser af de ændrede livsbetingelser som sygdommene forårsager, medfører ændringer i og omfattende arbejde med identitet som igen har betydning for hverdagslivet og de relationer, der udspiller sig her. Schippee et al.'s analyse af, hvorledes tiltagende sygdomskompleksitet kommer til udtryk i skiftende og individuelt varierende balancer mellem sygdomsbyrde og behand- 
lingsbyrde bidrager yderligere til forståelse af det identitetsarbejde, der finder sted hos multisyge. Forskning om patientinddragelse og multisygdom har haft fokus på hverdagsliv som en hindring for at følge behandlinger (se fx Ravenscroft 2006, Morris et al. 2011). Med artiklen har vi ønsket at vende blikket mod, at hverdagslivet integreres i beslutninger om og planlægning af behandling (se fx Bower et al.'s forskning 2012). I litteraturen beskrives multisyges udfordringer i hverdagen ofte som manglende overblik over behandlinger, dårlig compliance og manglende sundhedskompetencer. Dertil kommer, at det sociale liv påvirkes, relationer indskrænkes, og der pågår et kontinuerligt identitetsskift mellem det at se sig selv som syg og/eller som rask. Artiklens cases illustrerer samme pointer, men argumenterer for, at der ikke er tale om en compliance eller sundhedskompetenceproblematik, men snarere at særligt multisyge patienter har brug for at blive inddraget $\mathrm{i}$ beslutninger om behandling og pleje, fordi kompleksiteten af deres sygdomsforløb påvirker hverdagen i betydelig grad, hvilket har indflydelse på prioriteringer i behandling og egenomsorg.

\section{Noter}

1: Undersøgelsen er gennemført i et samarbejde mellem Danske Patienter og CFK Folkesundhed og Kvalitetsudvikling, Region Midtjylland. Undersøgelsen er finansieret af regeringens satspulje udbudt af Sundhedsstyrelsens ulighedspulje. Formålet med studiet er at undersøge, hvilke faktorer, der har betydning for kort-uddannede multisyge patienters håndtering af sygdoms- og behandlingsbyrde. Det sker med henblik på at kunne pege på initiativer, der kan bidrage til at reducere uligheden i sundhed blandt gruppen af mennesker med flere samtidige diagnoser. I den artikel behandles uligheds problematikken ikke eksplicit.

2: Litteraturstudiet bestod af en systematisk gennemgang af international litteratur med fokus på at fastlægge parametre af betydning for social ulighed blandt multisyge. Der blev søgt i fem databaser: Cochrane, PubMed, CINAHL, EMBASE, Science citation index. Desuden er der gennemført kædesøgninger baseret på litteraturhenvisninger fundet i relevante studier. Der blev søgt på følgende ord, enkeltvis og i kombinationer: Multimorbidity, Comorbidity, Chronic diseases, Patient attitude, Patient Perspective, Qualitative, Inequality, Inequity, Socioeconomic (factors), Self management, Disease burden, Intervention. Litteraturstudiet dannede afsæt for den videre undersøgelse, der er designet som antropologisk feltarbejde.

3: Fokusgruppeinterview blev gennemført med i alt 17 patienter med multisygdom i henholdsvis Storkøbenhavn og Midtjylland. Udvælgelseskriteriet for deltagelse var:

- min. tre kroniske lidelser

- ca. 1/3 af deltagerne skulle have depression, angst eller lignende sindslidelse i tilknytning til deres somatiske lidelser, svarende til den forventede forekomst 
- primært inden for den erhvervsaktive alder (18-67 år)

- ufaglært/faglært/kort boglig uddannelse

- min. fire kontakter til sundhedsvæsenet inden for det sidste år.

Patienterne blev rekrutteret gennem Gigtklinikken ved Regionshospitalet Silkeborg, Klinik for Multisygdom ved Diagnostisk Center, Regionshospitalet Silkeborg og i Københavnsområdet via patientforeninger og ophæng på ambulatorier, hos praktiserende læger og i venteværelser. Deltagerne drøftede, hvilken betydning sygdommene har for hverdagslivet og hvad 'der fylder' i hverdagen, hvordan de prioriterer, vælger og fravælger aktiviteter og tilbud, deres brug af sundhedsvæsenet og hvilke barrierer de oplever i forhold til sundhedsvæsenet. Fokusgruppeinterview fungerede som indledning på feltarbejdet, og formålet var at få indblik i centrale temaer og problematikker for de multisyges samarbejde med sundhedsvæsenet.

\section{Referencer}

van der Akker M (1996) "Comorbidity and multimorbidity: what's in a name? A reveiw of literature". In: Buntinx F, Knottnerus JA, (eds.) Eur J Gen Pract. 2, 65-70. 2-2-1996.

van der Akker M, Buntinx F, Metsemakers JF, Roos S, Knottnerus JA (1998) "Multimorbidity in general practice: prevalence, incidence, and determinants of co-occurring chronic and recurrent diseases" In: J Clin Epidemiol, May;51(5):367-75.

Aujoulat, I, Marcolongo, R, Bonadiman L \& Deccache, A (2008) Reconsidering patient empowerment in cronic illness : A critique of models of self-efficacy and bodily control. Social Science \& Medicine, 66(5):1228-1239

Barnett K, Mercer SW, Norbury M, Watt G, Wyke S \& Guthrie B (2012) “Epidemiology of multimorbidity and implications for health care, research, and medical education: a cross-sectional study" In: Lancet Jul 7;380(9836):37-43

Bauman AE, Fardy H \& Harris PG (2003) "Getting it right: why bother with patient-centered care?" In: Medical Journal Aust. 2003; 179;253-6.

Bertakis KD \& Azari R (2011) "Patient-centered care is associated with decreased health care utilization" In: Journal of American Board Family Medicine, 2011; 24; 229-39.

Bower et al. (2012) "Illness representations in patients with multimorbid long-term conditions: qualitative study" In: Psychological Health 2012;27(10):1211-26

Coulter A \& Ellins J (2006) Patient-focused interventions: a review of the evidence. Picker Institute Europe and the health foundation, QQUIP - Quest for Quality and Improved Performance, London.

Fortin M, Dubois MF, Hudon C, Soubhi H \& Almirall J (2007) “Multimorbidity and quality of life: a closer look" In: Health Qual Life Outcomes 2007;5:52.

Freil M \& Knudsen JL (2009) "Brugerinddragelse i Sundhedsvæsenet" In: Ugeskrift for Lxger 171 (20):1694.

Fudge N, Wolfe CDA, \& McKevitt C (2007) "Assessing the promise of user involvement in health service development: ethnographic study". In: BMJ. Vol. 336, No. 7639 (Feb. 9, 2008), pp. 313-317. 
Greenfield S, Kaplan SH, Ware JE, Jr., Yano EM, and Frank HJ. (1988) “Patients' participation in medical care: effects on blood sugar control and quality of life in diabetes" In: J.Gen.Intern.Med. 1988; 3(5):448-57.

Jenkins, R. [1996] (2006). Social Identitet. (D.K. Nielsen, Trans.). Academica.

Lawson KD, Mercer SW, Wyke S, Grieve E, Guthrie B, Watt GC (2012) “Double trouble: The impact of multimorbidity and deprivation on preference-weighted health related quality of life a cross sectional analysis of the Scottish Health Survey" In: International Journal for Equity in Health 2012(1):67.

Mathiesen T, Willaing I, Freil M, Jørgensen T, Andreasen AH, Ladelund S \& Harling H (2007) How do patients with colorectal cancer Perceive treatment and care compared with the treating health care professionals? Medical Care, vol. 45, no. 5.

Meillier LM, Nielsen KM, Larsen FB \& Larsen ML (2012) "Socially differentiated cardiac rehabilitation: Can we improve referral, attendance and adherence among patients with first myocardial infarction?" In: Scand J Pub Health 2012;40:286-293.

Mollerup M, Martin HM \& Bech M (2010) "Effektiv brugerinddragelse - foreløbige erfaringer fra projekt PaRIS". In: Tidsskrift forsundhedsvæsen. Maj 2010.

Morris RL, Sanders, C, Kennedy, AP \& Rogers (2011) A. Shifting priorities in multimorbidity: a longitudinal qualitative study of patient's prioritization of multiple conditions

Cronic Illness 7(2):147-161

Moth G, Vestergaard M \& Vedsted P (2012) "Chronic care managment in Danish general practice - a cross-sectional study of workload and multimorbidity" In: BMC Family Practice, 2012, 13:52

Ravenscroft EF (2008) Patient Perspectives on Health Care System Navigation: the Chronic Illness Multi-Morbidity Experience. 2008, Thesis, Faculty of Graduate Studies, The University of British Columbia

Reventlow S, Kragstrup J, Guassora AD, Bjerrum L \& Olivarius NdeL (2013) "Multimorbiditet $\mathrm{i}$ et sundhedsvæsen, som er indrettet til enkeltsygdomme" In: Ugeskr. Læger 2013;175(16):1093

Roland M. \& Paddison M. (2013) "Better management of patients with multimorbidity" In: BMJ 2013;346:f2510

Sells, D, Sledge, WH, Wieland, M, Walden, D, Flanagan, E, Miller, R, \& Davidson, L (2009)

Cascading crises, resilience and social support within the onset and development of multiple chronic conditions. Chronic Illness 5: 92-102

Sharry, JJ, Bishop, FL, Moss-Morris, R \& Kendrick, T (2013) "The chicken and egg thing": Cognitive repræsentations and self-management of multimorbidity in people with diabetes and depression. Psychology \& Health 28(1):103-119

Shippee, ND, Shah, ND, May, CR, Mair FS, \& Montori, VM (2012) Cumulative complexity: a functional, patient-centered model of patient complexity can improve research and practice. Journal of Clinical Epidemiology 65:1041-1051

Smith SM, O'Kelly S \& O'Dowd T (2010) GPs' and pharmacists' experiences of managing multimorbidity: A 'Pandora's box'. British Journal of General Practice60(576): July.

Sundhedsstyrelsen (2014) Danskernes sundhed - den nationale sundhedsprofil 2013. København: Sundhedsstyrelsen 2014

Sørensen K, Nørgaard O \& Maindal HT (2014) "Behov for mere forskning i patienters sundhedskompetencer" I: Ugeskr Læger, 176/1, p. 40-43 
Tinetti ME, McAvay GJ, Chang SS, Newman AB, Fitzpatrick AL \& Fried TR (2011) “Contribution of multiple chronic conditions to universal health outcomes" In: J Am Geriatr Soc 2011 September;59(9):1686-91.

Uijen AA \& van de Lisdonk EH (2008) "Multimorbidity in primary care: prevalence and trend over the last 20 years" In: Eur J Gen Pract;14 Suppl 1:28-32.

Weingart SN, Zhu J, Chiappetta L, Stuver SO, Schneider EC, Epstein AM, David-Kasdan JA, Annas CL, Fowler FJ \& Weissman JS (2011) “Hospitalized patients' participation and its impact on quality of care and patient safety". In: Int J Qual Health Care. 2011 June; 23(3): 269-277.

WHO chronic diseases (2013). http:/www.who.int/topics/chronic diseases/en/. Hentet 10/4 2014

ViBIS(2014a) http://vibis.dk/om-brugerinddragelse/definition-af-brugerinddragelse hentet $10 / 42014$

Wolff JL, Starfield B \& Anderson G (2002) "Prevalence, expenditures, and complications of multiple chronic conditions in the elderly" In: Arch Intern Med Nov 11;162(20):2269-76. 